\title{
Optimizing Irrigation and Young Tree Management ${ }^{1}$
}

\author{
Davie Kadyampakeni and Sandra Guzmán²
}

\section{Importance of Irrigation}

Young citrus trees require optimal irrigation management for vigorous vegetative growth, leaf flushing, and establishment of a dense canopy. Poor irrigation practices, such as infrequent irrigation or irrigating without using irrigation scheduling tools, could be costly. Besides excessive loss of water and nutrients, the growth of young trees might be impacted by an excess or deficit of water. Crop water stress in young trees directly affects yield and fruit quality. In this article, we cover some strategies for optimizing young tree care and irrigation management to in turn optimize grove efficiency and productivity.

\section{Strategies for Accelerating Young Tree Growth \\ Use of Reflective Mulch}

Installation and use of reflective mulch in the past 5-10 years has shown to be effective for improving the establishment and performance of young trees. Besides saving water due to limited evaporation, the reflective mulch also repels the Asian citrus psyllid (the pest that transmits the pathogen that causes citrus greening) and regulates soil temperature. In addition, because most of the water is delivered within 6 to 10 inches of the root zone, nutrient and water uptake are increased significantly, resulting in vigorous tree growth. This results in establishment of a promising citrus grove that can sustain retention of the first fruit load in the era of citrus greening.

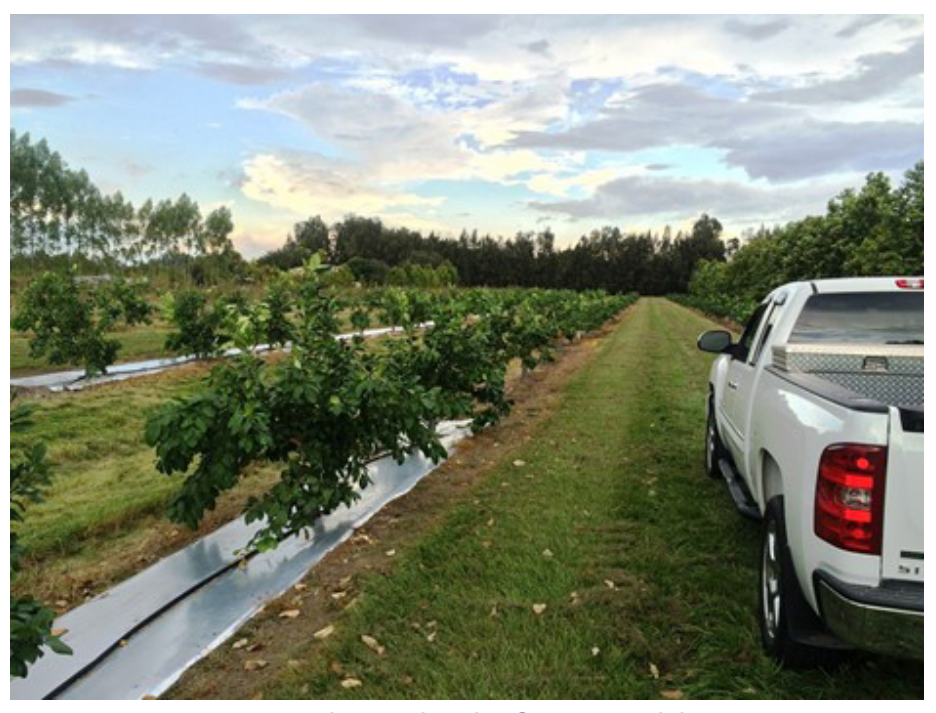

Figure 1. Young trees with metalized reflective mulch. Credits: Bob Adair, Florida Research Center for Agricultural Sustainability

\section{Plastic-Fabric Mulch Covers}

Plastic covers appear to both increase water storage in the soil and limit evaporation, thereby promoting water use efficiency. In studies conducted on the Ridge and Flatwoods, greater water retention and faster growth, compared to bare ground, were achieved with these covers. Preliminary insights from plastic-fabric mulch groundcovers can be found at https://citrusindustry.net/2020/04/14/ fabric-mulch-groundcovers-save-water/.

1. This document is SL488, one of a series of the Department of Soil and Water Sciences, UF/IFAS Extension. Original publication date April 2021. Visit the EDIS website at https://edis.ifas.ufl.edu for the currently supported version of this publication.

2. Davie Kadyampakeni, assistant professor, Department of Soil and Water Sciences, UF/IFAS Citrus Research and Education Center; and Sandra Guzmán, assistant professor, Department of Agricultural and Biological Engineering, UF/IFAS Indian River REC; UF/IFAS Extension, Gainesville, FL 32611.

The Institute of Food and Agricultural Sciences (IFAS) is an Equal Opportunity Institution authorized to provide research, educational information and other services

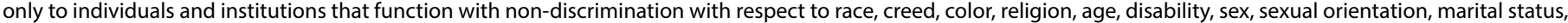

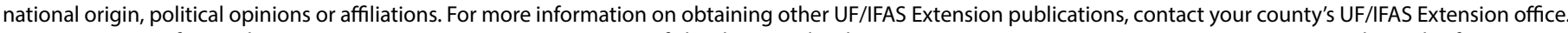
U.S. Department of Agriculture, UF/IFAS Extension Service, University of Florida, IFAS, Florida A \& M University Cooperative Extension Program, and Boards of County Commissioners Cooperating. Nick T. Place, dean for UF/IFAS Extension. 


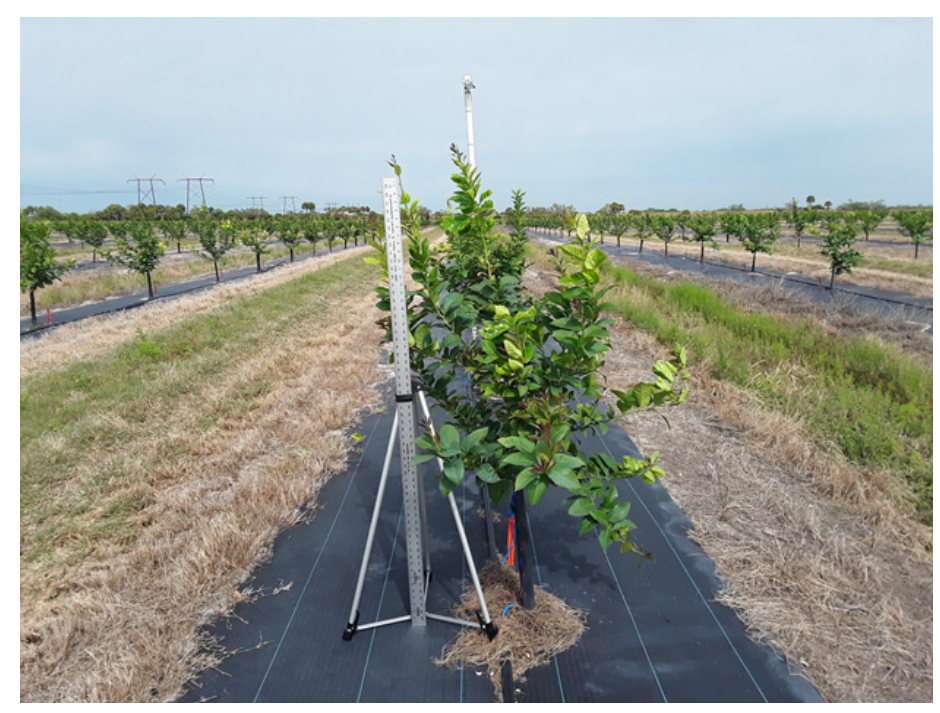

Figure 2. Young trees with plastic cover.

Credits: Eduart Murcia, UF/IFAS Indian River Research and Education Center

\section{Frequent Irrigation Using Readily Available Tools}

More importantly, frequent irrigation is a key strategy for enhancing the performance of young trees. Tools readily available include soil moisture sensors, weather stations (Florida Automated Weather Network stations, available at https://fawn.ifas.ufl.edu/, or commercially available weather stations), and irrigation apps. There are at least seven different operating principles used by various brands of electronic soil water sensors: time domain reflectometry (TDR), time domain transmission (TDT), frequency domain reflectometry, amplitude domain reflectometry, phase transmission, tensiometer, and resistance granular matrix sensors. For Florida sandy soils, it appears the use of the capacitance, TDT, and TDR sensors is appropriate due to low maintenance requirements. The installation procedures for these sensors and interpretation of soil moisture are available, and their advantages and suitability for irrigation scheduling on sandy soils have been discussed before by several authors (see https:/citrusindustry.net/2017/07/10/ understanding-soil-moisture-sensor-data/ and https:// citrusindustry.net/2018/07/10/using-soil-moisture-sensorsfor-citrus-irrigation/). For sensors requiring further calibration, information on the equations for calibrating different brands of soil moisture sensors are provided by https:// www.mdpi.com/2073-4441/12/2/358, https://link.springer. com/article/10.1023/A:1017915114685, and https://doi. org/10.2136/sssaj2008.0264.

Use of weather stations and smartphone irrigation apps for proper irrigation scheduling and determination of water budgets has been discussed by researchers (https://edis.ifas. ufl.edu/ss660). These are cost-effective ways of reducing water inputs and increasing water savings in citrus production operations by real-time monitoring of water use or crop evapotranspiration, rainfall, and irrigation events.

\section{Optimal Fertigation Schedule}

The right timing and placement of fertilizer in the root zone is important to ensure increased uptake of nutrients. Use of fertigation for young trees increases water and nutrient availability in the root zone, minimizes nutrient leaching, enhances nutrient uptake, and promotes root-length density distribution around the tree. Information regarding the right amounts of fertilizer to apply for young trees is available in the 3rd edition of Nutrition of Florida Citrus Trees (https://edis.ifas.ufl.edu/ss478).

\section{Concluding Summary}

In summary, use of irrigation scheduling tools, weather stations, and irrigation apps is important in managing young citrus groves and ensuring improved grove production efficiency. In addition, some tools that growers have for establishing young citrus groves, such as reflective mulch and plastic fabric covers, can also improve water savings, control pests, and improve nutrient retention, while also promoting vigorous tree growth and potentially improving early fruit yields. 